\title{
ADLib システムを用いたモノクローナル抗体の迅速作製
}

\author{
太田邦史, ${ }^{*}, a$ 瀬尾秀宗 $b$
}

\author{
ADLib System for Rapid and Flexible Design of Monoclonal Antibodies \\ Kunihiro OHTA, ${ }^{*}, a$ and Hidetaka $\mathrm{SEO}^{b}$ \\ ${ }^{a}$ Genetic System Regulation Laboratory, RIKEN Discovery Research Institute, 2-1 Hirosawa, Wako City, Saitama \\ 351-0198, Japan, and ${ }^{b}$ Chiome Bioscience Inc., 2-39-11 Hongo, Bunkyo-ku, Tokyo 113-0033, Japan
}

(Received August 28, 2006)

\begin{abstract}
Monoclonal antibodies (MAbs) have been utilized as research tools, as diagnostic reagents, and for antibody medicine. The preparation of MAbs involves laborious processes and normally takes months. Here we describe an ex vivo B cell-based antibody display system called the ADLib (Autonomously Diversifying Library) system, which enables us to select chicken B cell clones producing antibody against antigens of interest in a couple of weeks. The ADLib system is applicable to self- or highly conserved antigens, polysaccharide chains, peptides, and haptens.
\end{abstract}

Key words — monoclonal antibody; antibody engineering; ADLib system; immunoassay; chicken DT40 cell line

\section{1. 序論}

均一の性質を持ち，無限に生産可能なモノクロー ナル抗体は, 1975 年に Köhler と Milstein によって 報告1)されて以来，研究試薬や診断薬，そして近年 では抗がん剂などの抗体医薬品として盛んに利用さ れている。現在一部の HER2/erbB2 リセプターを 高発現する乳癌の治療に用いられているハーセプチ ン（HER2/erbB2 リセプターを標的とするモノク ローナル抗体製剂）は，化学治療や外科治療と併用 することで極めて顕著な効果があり，抗体医薬品の 成功例の 1 つであろう。これらの実用上の成功によ り，モノクローナル抗体の市場は年々拡大している. 標準的なモノクローナル抗体作製法では，抗原を マウスなどに注射して免疫刺激を行い, 脾臓を摘出 して B リンパ球を含む細胞集団を獲得する。つい で，抗体を産生する B リンパ球とミエローマ細胞 を融合させてハイブリドーマを作製し，その後何段 階かの限界希釈と酵素免疫アッセイ（ELISA）な どのスクリーニング手法により，目的の特異抗体を

a独立行政法人理化学研究所中央研究所太田遺伝システ ム制御研究室 (干351-0198 埼玉県和光市広沢 2-1),

$b$ 株式会社カイオム・バイオサイエンス（†113-0033 東京都文京区本郷 2-39-11 アロニアビル 2F)

*e-mail: kohta@riken.jp

本総説は, 日本薬学会第 126 年会シンポジウム S23 で 発表したものを中心に記述したものである.
産生するハイブリドーマクローンを選別する．この 過程は実験動物への抗原の免疫を含むため，免疫寛 容の問題が存在し，種間でよく保存されたタンパク 質や自己抗原・糖鎖などの抗原性の低い抗原などに 対するモノクローナル抗体が得難いという問題が指 摘されてきた。また，毒素や病原体など，免疫によ つて動物個体の生存が困難になるものについても抗 体が得難いという欠点がある。ささらには，モノク ローナル抗体作製過程は時間と労力の掛かる工程が 多く，作製の経済的・時間的コストも大きい，筆者 もかつてモノクローナル抗体を作製した経験がある が，一定水準のスキルを持つ経験者がある時期集中 して張り付いて実験する必要があり，なんとかこれ らの工程を改善・簡素化できないかと感じていた.

これらの問題点を克服する手法として，ファージ ディスプレイ法に代表される生体外抗体作製系が開 発されている。1985 年に Smith らによって報告さ れたファージディスプレイ法22では，抗体の抗原結 合部分をファージ粒子遺伝子に組み込み，ファージ 粒子の一部に抗体を提示したファージ抗体を作製す る.この際, 莫大な数の抗原結合部位遺伝子をフ アージ粒子タンパク質に融合させるべくファージゲ ノムに組み込み，ファージ抗体ライブラリーを作製 する.これらライブラリーから，抗原を用いたバイ オパニングにより，目的の抗原に対して結合するフ 
アージ抗体を選択するのである。この手法により多 数の抗体が作製されているが，完全抗体の製造には 組換え DNA 操作を必要とする点や，良質なライブ ラリーの確保，高親和性のファージ抗体の選択技 術，などの点で技術的なボトルネックが存在するこ とが知られている。

前述の通り, バイオ医薬としてのモノクローナル 抗体の重要性は年々増大している，免疫寛容を超え て多数の有用抗原に対するモノクローナル抗体を, 迅速かつ効率的に作製する技術が必要とされている 時代である，本稿では，筆者らのグループが最近生 み出した，これらの課題を克服する新原理に基づく わが国初の抗体作製技術，ADLib システムについ て紹介する。

\section{ADLib システムの基本原理}

筆者らのグループは，ニワトリの B リンパ球培 養細胞株である DT40を用いて，モノクローナル抗 体を生体外で迅速に作製する ADLib システムを開 発した. ${ }^{3)}$ この技術のベースとなっていたのは，酵 母細胞を用いた基礎研究成果である。われわれは, 10 年以上の研究の過程で, クロマチン構造の再編 成やヒストンアセチル化が分裂酵母の減数分裂期相 同組換えの部位特異的活性化に必要であることを見 出した. ${ }^{4,5}$ この現象の高等真核生物における一般性 を検証する目的で，ニワトリの bursa of Fabricius の B リンパ球をトランスフォームして不死化した 培養細胞株 DT40 細胞に着目した。

DT40 培養細胞株は, Buerstedde と武田らによっ て樹立されたニワトリ B 細胞株であり, 6-8) 1） IgM 抗体産生・分泌能，2）細胞表面への IgM の提示, 3) 抗体可変領域における低頻度の遺伝子再編成，4） 無限増殖能，5）高増殖能（倍加時間 7-8 時間），6) 高頻度相同組換え，7）核型の安定維持能，などの 顕著な特質を持つ。この細胞は産生した抗体 (IgM) を細胞表面へ提示するため，ファージディスプレイ のようなバイオパニングを行うことで, 生体外で抗 体を作製することが原理的には可能である。しか し, 高レベルの抗体可変領域における遺伝子再編成 を実現して，抗体作製に必要なレパートリーを確保 することは，現実的には困難であった。加えて， DT40 を利用した研究のほとんどは, 様々な遺伝子 ノックアウト細胞を作製し，その表現型を観察する という方向に傾倒していたことから，こうした試み
は報告されていなかった。

筆者らのグループでは, 酵母で得られた知見を検 証する目的で，まず抗体可変領域遺伝子で生じる ジーンコンバージョンという相同組換えの一種が, ヒストンアセチル化でどのように制御されているか に関心を持った。前述の通り, それまでの酵母減数 分裂期相同組換えの研究から「クロマチン構造やヒ ストンアセチル化が局所的な相同組換え頻度を調節 している」という知見を得ていたが，これを高等真 核生物で検証する目的で DT40 のジーンコンバージ ヨンに着目した。

DT40 を含むニワトリ B 細胞では，母親・父親由 来染色体に存在する計 2 つ抗体可変領域遺伝子の うち，一方のみが V（D） J 組換えにより転写活性 型に転換される。抗体軽鎖遺伝子の場合，上流に 25 個存在する可変領域に相同な配列（偽抗体遺伝 子セグメント）を鋳型に，この活性型可変領域遺伝 子に向けて一方向性のコピー変換（相同組換えの一 種）が起きる (Fig. 1). ${ }^{8)}$ この現象をジーンコンバー ジョンといい，これによって抗体遺伝子座のシャフ リングが起き, 可変領域の多様性が生じる. DT40 細胞株ではこのジーンコンバージョンが低頻度なが ら起きることが知られている。しかしながら，この 頻度はかなり低いため（2-3 週間の培養で数\%程 度)，抗体作製に利用できるほどのレパートリーは 通常得られない。

筆者らは DT40 を用いて, 活性型の可変領域遺伝 子と不活性な可変領域遺伝子でアセチル化ヒストン のレベルを比較した. ${ }^{3)}$ その結果, 活性型可変領域 で高レベルのアセチル化が確認された。この結果を

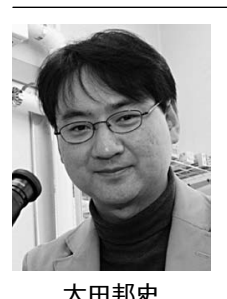

太田邦史
独立行政法人理化学研究所中央研究 所・太田遺伝システム制御研究室准主 任研究員. 昭和 60 年東大理学部生物化 学科卒, 平成 2 年東大大学院理学系研 究科生物化学専攻博士課程修了。日本 学術振興会特別研究員 (DC・PD) を 経て平成 3 年理化学研究所研究員. 平 成 12 年より研究ユニットリーダーとし て研究室を主宰. 平成 18 年より現職.「真核生物の相同 組換え開始機構」が主要テーマ.この基礎研究の一環と して，指導していた当時東大院生の瀬尾氏が TSA による DT40 の組換え活性化現象を見出し，ADLib システムの 確立に至った。ADLib システムの開発で，2006 年度 Invitrogen-Nature Biotechnology 賞（ベンチャー部門）受 賞. 将来は相同組換えの制御に関する基礎と応用の両面 展開を考えている. 
さらに検証するために，ヒストン脱アセチル化阻害 剂であるトリコスタチンA（TSA: trichostatin A） によりDT40 を処理した（Fig. 2)。その結果，抗 体可変領域遺伝子のヒストンアセチル化の昂進とと もに，組換え頻度が著しく上昇し，3 週間程度の処 理で 50-90\%以上もの細胞がジーンコンバージョ ンを起こすことが明らかになった（Fig. 3)。つま り，抗体可変領域のヒストンアセチル化レベルを TSA で強化することにより，抗体遺伝子のジーン コンバージョンを促進し，DT40 の抗体遺伝子レ パートリーを人為的かつ自律的に増大させられるこ とが明らかになった。

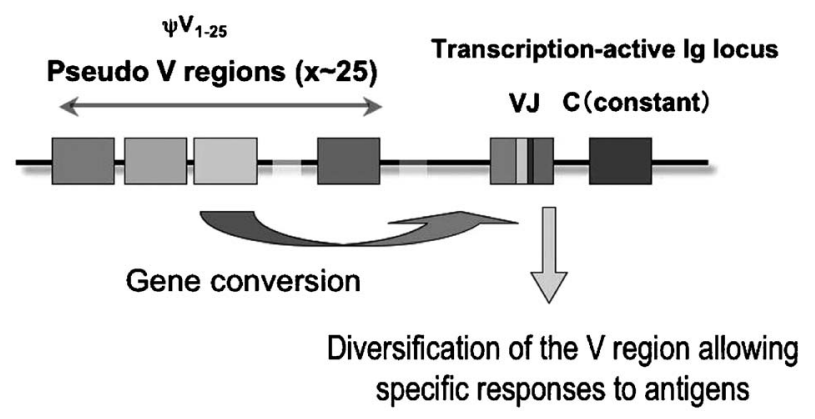

Fig. 1. Schematic Drawing of Chicken Ig Locus (Recombination Ative Type) V (D) J Recombination Takes Place in One of Two Chicken Ig Loci to Generate the Transcriptional and Recombinational Active Ig Allele

Gene conversion occurs unidirectionally and continuously from the upstream pseudo $\mathrm{V}$ segments (25 segments in case of $\operatorname{IgL}$ ) to the recombined IgL and IgH V regions. Such gene conversion events create diversity of the IgL and IgH $\mathrm{V}$ regions in chicken B-cells.
次に筆者らは, TSA 処理によって多様化した 1 億個程度の DT40 細胞で構成された B 細胞ライブ ラリー (ADLib : Autonomously Diversifying Library）を準備し，磁気ビーズに固定化した抗原を用い て抗原に親和性を持つ抗体を細胞表面に提示したク ローンを選別し，限界希釈後にクローンを増殖させ た（Fig. 4). 3)このクローンについて蛍光セルソー ター（FACS）で表面 IgM の抗原に対する親和性・ 特異性を調べたところ，目的の抗原に対して特異的 かつ強い結合が観察された。また，増殖後のクロー ンが培養上清に分泌する抗体について，ELISA な どの手法で特異性・親和性を調べられることも判明 した（Fig. 5)。ELISA を利用することで，より迅 速に目的の性能を持つ抗体産生細胞を選別すること が可能となった．なお，DT40 は増殖が大変速いた め，あらかじめライブラリーさえ用意できていれ ば，選別過程には 1 週間ほどしか掛からない。後述 する通り，この方法で多様かつ多数の抗原に対する 抗体の迅速作製に成功した．筆者らは，この方法を そのライブラリー名にちなんで ADLib システムと 呼んでいる。

\section{ADLib システムの特徵}

ADLib システムの特徵は, 「迅速性」と「柔軟性」 という言葉に代表される（Table 1)。まず，迅速性 であるが，あらかじめ ADLibを作製して ADLib システムを適用すれば，従来半年ほど掛かっていた モノクローナル抗体産生クローンの選抜が， 1-2

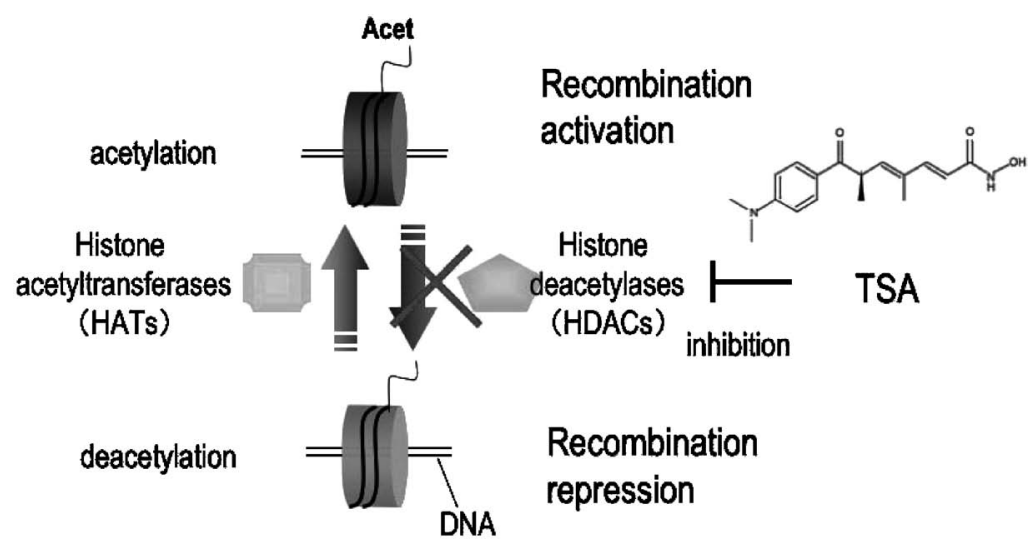

Fig. 2. Histone Acetylation and Recombination

In fission yeast meiosis, histone acetylation is involved in local activation of homologous recombination. In vivo levels of histone acetylation are determined by the ratio of counteracting actions by histone acetyltransferases (HATs) and histone deacetylase (HDAC). Hence, when the cell is treated with HDAC inhibitors, histone acetylation levels increase in the cell. Trichostatin A(TSA) inhibits type I HDACs, so that the treatment of cells with TSA results in enhancement of histone acetylation. Since TSA has been shown to induce V (D) J recombination in mouse B cells, we thought that the TSA treatment of DT40 might induce gene conversion locally at recombination active Ig allele. 


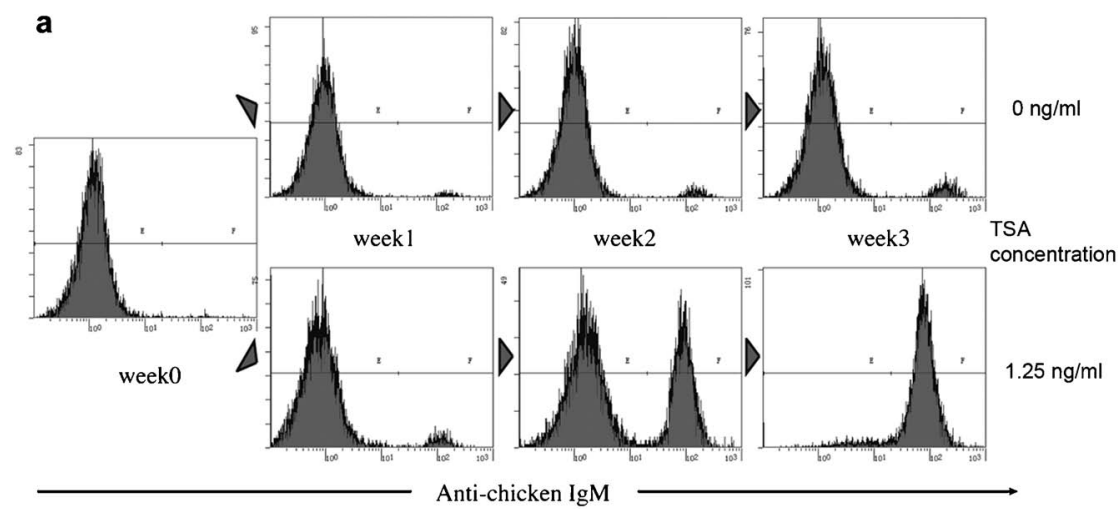

b
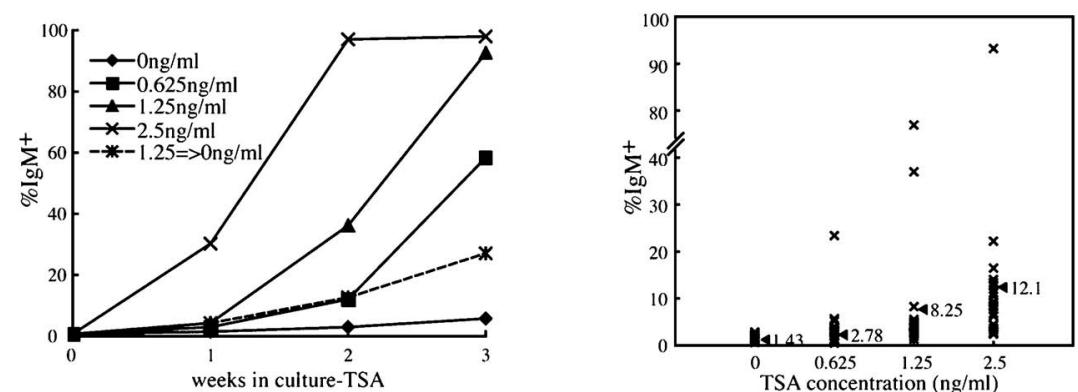

Fig. 3. TSA Enhances Gene Conversion at the Functional Chicken Ig Locus Prolonged TSA Treatment (Several Weeks to 2 Months) Causes Autonomous Diversification of Both IgH and IgL V Regions

The figure illustrates diversification of IgL V regions. a: gene conversion monitored by FACS. The DT40 CL18 clone has a frameshift mutation in the complementarity determining region-1 (CDR1), thereby no surface IgM is produced. When some gene conversion events rescue this frameshift mutation, then CL18 can produce surface IgM, which can be detected by FACS with fluorescein-conjugated antigens. Note that most of cells are converted to surface IgM positive in the presence of TSA, but little without TSA. b: the time courses of experiment a. If TSA treatment is terminated, we detect a marked slowdown of the rate at which population of surface IgM positive cells increases. c: the dose dependence experiments starting from a single isolated CL18 clone (fluctuation test). Data are from Ref. 3).
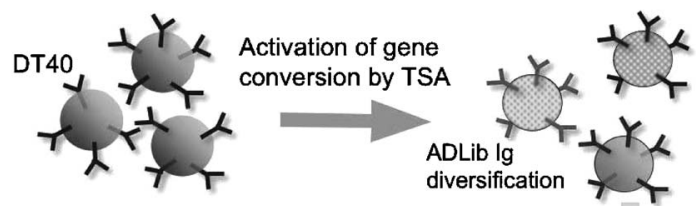

Selection using magnetic beads: duration $\sim 1$ week

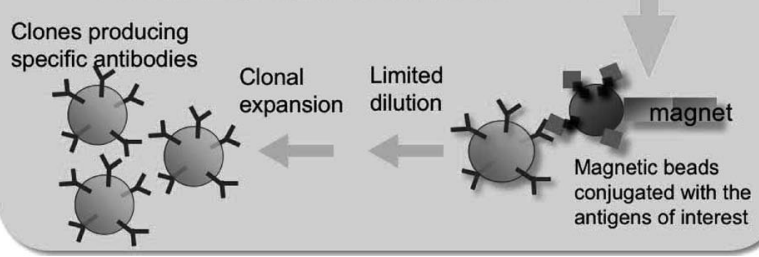

Fig. 4. ADLib System

Scheme of ADLib system. Once ADLib has been prepared, screening steps require about one week, since DT40 can grow very fast.

週間程度の短期間で可能になる. 1-2 週間という 短期間で，ある程度抗体作製の見当が付く点は，実 際に系を動かしてみると大変好都合である。通常の 手法で抗体作製がうまくいかないケースは，抗原の
構造変化や物質的特性, 純度などの問題を含むケ一 スが多い。これらの問題点の多くは，一度 ADLib システムを稼働させてみることにより, 早期に顕在 化することができる。したがって，1-2 週間後に は, 別のアプローチから調製したり, 磁気ビーズへ の抗原結合方法の改善を行ったりして, より可能性 の高い抗体調製プログラムを策定することができ る. 通常の手法では, このフィードバックまでの期 間が数カ月以上になるので, ADLib システムの導 入で実験効率の著しい改善が期待されることになる.

柔軟性という観点では，1）適用可能な抗原範囲 が広いこと，2）親和性向上やクラス転換など事後 的に抗体の性能をチューンアップできること, が挙 げられる。まず，ADLib システムは完全な生体外 モノクローナル抗体作製系であるため，動物体内で みられる免疫寛容の制限をほとんど受けない。した がって，これまでモノクローナル抗体作製が困難だ つた抗原，例えば種間で非常によく配列が保存され 
a

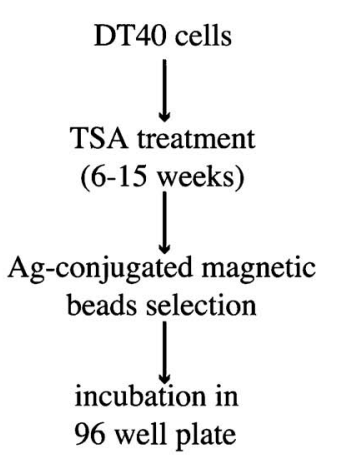

C

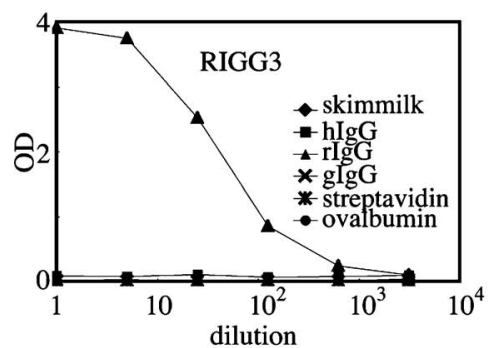

b

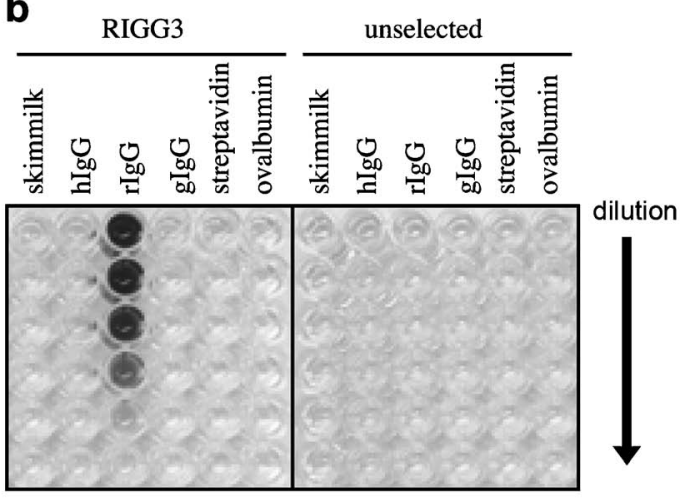

d

Fig. 5. Design of Anti-rabbit IgG Monoclonal Antibody by ADLib System

Rabbit IgG is conjugated to magnetic beads, and DT40 clones in ADLib are contacted with the rabbit IgG-magnetic beads. a: the scheme of selection. b and c: data of ELISA for the specificity check of anti-rabbit IgG monoclonal antibody (RIGG3). Note that the antibody is only reactive with rabbit IgG (rIgG), but not other unrelated antigens such as skimmed milk, human IgG (hIgG), goat IgG (gIgG), streptavidin, and ovalbumin. d: affinity measurements using surface plasmon resonance. The dissociation constant is estimated to $47 \mathrm{~nm}$ in this experiment. Data are from Ref. 3).

Table 1. Comparison between ADLib System and Other Methods for Monoclonal Antibody Preparation

\begin{tabular}{llll}
\hline \hline & \multicolumn{1}{c}{ ADLib system } & $\begin{array}{c}\text { Conventional method of } \\
\text { monoclonal antibody } \\
\text { preparation }\end{array}$ & \multicolumn{1}{c}{ Phage display } \\
\hline Applicable antigens & $\begin{array}{l}\text { Any types including autoanti- } \\
\text { gens and toxins }\end{array}$ & $\begin{array}{l}\text { Limited to antigens recogniza- } \\
\text { ble as foreign material }\end{array}$ & $\begin{array}{l}\text { Any types including autoanti- } \\
\text { gens and toxins }\end{array}$ \\
\hline Speed & $1-2$ weeks & $2-6$ months & $>10$ weeks \\
\hline Amount of antigen required & $\begin{array}{l}<100 \mu \mathrm{g} \text { (including antigen } \\
\text { used for ELISA) }\end{array}$ & $>$ Hundreds of $\mu \mathrm{g}-\mathrm{mg}$ & $>$ Hundreds $\mu \mathrm{g}$ \\
\hline Type of antibody & Full antibody & Full antibody & Phage antibody \\
\hline Automation & Suitable & Difficult & Possible \\
\hline Required facility & Basic laboratory facility & Animal facility & Recombinant DNA facility \\
\hline $\begin{array}{l}\text { Customization of designed } \\
\text { antibody }\end{array}$ & $\begin{array}{l}\text { Convertible to IgG type } \\
\text { (mouse and human) }\end{array}$ & $\begin{array}{l}\text { Possible by recombinant } \\
\text { DNA technique }\end{array}$ & $\begin{array}{l}\text { Possible by recombinant } \\
\text { DNA technique }\end{array}$ \\
\hline
\end{tabular}

ている抗原や，ペプチドなどの低分子，毒素などに も適応可能である.

また，DT40 は遺伝子破壊株を作製することも容 易である。この性質を利用し，抗体産生クローンの ジーンコンバージョンに必要な酵素である AID (Activation Induced Cytidine Deaminase) 遺伝 子9-12)をノックアウトし，モノクローナル抗体遺伝
子の安定保持を実現している. さらには, 相同組換 えに係わる XRCC3 遺伝子のノックアウトを作製す ると, 抗体可変領域遺伝子に選択的に体細胞突然変 異が導入される. ${ }^{13)}$ いろいろな課題は存在するが, この XRCC3 遺伝子ノックアウトの効果を用いるこ とにより，既に入手したモノクローナル抗体の親和 性を向上させることも不可能ではない（後述）.以 
上の通り，DT40 の特質をフルに利用できる点が， ADLib システムの大きな長所となっている.

\section{ADLib システムの課題}

このように, ADLib システムにはいくつも長所 があるが, 現時点での課題もいくつか存在する. 特 に，現状では産生されるモノクローナル抗体のクラ スがニワトリ IgM 型である点が，1つの課題とな つている，やはり，試薬や医薬品などの用途を考え ると，マウスやヒトの IgG 型に転換することが重 要である。ただし，この問題については現在対応技 術の開発が急ピッチで進んでいる，加えて，診断薬 などへの利用を考えると，大量のモノクローナル抗 体の生産が必要となることから，DT40を用いた抗 体産生の高効率化実現を目指した研究も重要になつ ている.

また，ADLib システムで得られる抗体（IgM） の親和性（単個の結合部位）は, 表面プラズモン解 析機（Biacore）で測定すると多くの場合おおむね $10^{-8} \mathrm{M}$ 程度の解離定数を示す中程度のものである (Fig. 5)。抗体医薬などに使用するためには, $10^{-10--12} \mathrm{M}$ 程度の高親和性抗体が必要であると言 われており，親和性向上技術の確立も重要な課題と して残されている.

これに関しては，既に簡単に記したが，DT40 細 胞株を用いた一連の遺伝子機能解析研究の過程で明 らかにされているXRCC3 遺伝子（相同組換えに係 わる）破壊株を利用できるであろう．XRCC3 遺伝 子ノックアウト株では，抗体可変領域遺伝子に集中 的に体細胞突然変異が導入される13)が，その現象を 用いて抗体の親和性向上の試みがなされている. ${ }^{14)}$ この系では, 変異導入・バイオパニング・クローン 増殖のサイクルを数一十数回程度繰り返すことで, 特定抗原に対する抗体の親和性向上が可能になる が，抗体の作製系としてはいろいろな課題があるよ うである，例えば，この方法は複数回のサイクルを 実施する必要があること, また, XRCC3 遺伝子ノ ックアウト株は増殖が遅くなることから, 抗体産生 細胞の入手には相当な時間と手間が掛かることが推 測される. 加えて, 得られた抗体の多くは, 複数回 の選択サイクルの実施により親和性の向上が起きる ものの, 多数の抗原に対する交叉反応性を示し，特 異性獲得に若干問題がある。したがって，XRCC3 遺伝子ノックアウト株を利用した親和性向上は，筆
者らの ADLib システムと組み合わせて真価が発揮 されるものと考えられる. 生体内の免疫システムで も, 組換えによって抗体の大まかなフレームが決定 し，ついで体細胞突然変異が生じることで親和性成 熟が起きることを考えれば，両者を組み合わせた抗 体作製系は非常に理にかなったシステムであると言 える.

\section{ADLib システムの実施例}

次に ADLib システムを用いたモノクローナル抗 体作製の実施例を示す。

\section{5-1. 一般的なタンパク質に対するモノクローナ} ル抗体作製例ＡDLib システムでは，現在ごく 一般的な可溶性タンパク質に対するモノクローナル 抗体作製についてはほぼ標準手順が固まり，スク リーニング回数の多䓖はあるものの, かなりの確率 で抗体の作製に成功する状態になっている（Fig. 5). ライブラリーに目的の抗体を産生する細胞が含 まれる場合は，通常は 1 回のスクリーニング（7 日 間）で数一数十個，多い場合は 100 個以上の抗原結 合性抗体産生クローンが得られる。場合によって は，この後さらに限界希釈を行って確実にクローン 化する．抗原によっては，目的の抗原以外の因子に も交差反応性を示す抗体が得られる。これに対して は，一次スクリーニング時に目的抗原と対照抗原を それぞれ結合させた ELISA 用 96 穴プレートを用 い，目的抗原にのみ反応性を示す抗体を産生する細 胞を選別すると，多くの場合目的抗原に高い特異性 を示す抗体を産生するクローンが分離できることが 判明した。この方法を用いることにより, 迅速に特 異性の高い抗体を産生するDT40 クローンを分離で きるようになった．得られたモノクローナル抗体に ついては, 約半数程度のクローンでイムノブロット での使用が可能なケースがあった。また，抗体産生 量は通常の培養で 0.5 一数十 $\mu \mathrm{g} / \mathrm{ml}$ の IgM を培養 上清に分泌し, 高密度培養法の導入により数百 $\mu \mathrm{g} /$ $\mathrm{ml}$ レベルの濃度で IgM 分子を獲得することが可能 である。

一般的な抗原で抗体作製の支障となるのは，主と して抗原の純度や安定性に問題があるケースであ る.この場合，単に単一の分子種であるというだけ でなく, 立体構造上の均一性も要求される。大腸菌 などで生産した抗原では, タンパク質のフォールデ ィングが均一でないため，良好な抗体のスクリーニ 
ングが実施できないケースもあるようである.

5-2. 自己抗原や種間で保存されたタンパク質な どに対するモノクローナル抗体の作製例 $\mathrm{AD}$ Lib システムは完全な ex vivo 抗体作製系であるた め，実験動物への免疫刺激を経ずにモノクローナル 抗体作製が実施できる。このため，動物体内では免 疫寛容や毒性などの問題で抗体作製が困難であった 抗原についても，抗体作製が可能になる．例えば， 自己抗原（ニワトリ由来卵白アルブミン，リゾチー ムなど）や，種間でアミノ酸配列が非常によく保存 されているタンパク質（ユビキチンなど）について ADLib システムを適用すると，比較的容易に特異 抗体を入手することができた，毒素については，現 在実施例はまだないが，将来的には中和型の抗体の 入手を目指して研究を進めている.

5-3. 抗原の立体構造を認識するモノクローナル 抗体の作製 ADLib システムでは, 細胞と磁気 ビーズの接触が比較的温和な条件かつ短時間で終了 するため, タンパク質の立体構造を認識するモノク ローナル抗体の作製に効力を発揮する。アミノ酸配 列上は同一であるが分泌成分の存在により構造が異

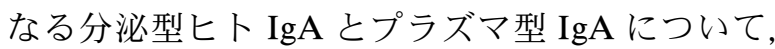
両者を識別するモノクローナル抗体の作製に成功し ている.さらに，創薬で重要な役割を持つ膜タンパ ク質（7 回膜貫通 $\mathrm{G}$ 蛋白質共役型受容体：GPCR など）についても，タンパク質を界面活性剤ミセル や細胞表面などに立体構造を保持する形で提示でき れば，ADLib システムで迅速にモノクローナル抗
体を作製できる可能性がある。このようにして得ら れたモノクローナル抗体の一部は，膜タンパク質な ぞの疎水性部位をマスクして立体構造を安定化する 働きがあることが予想され，X 線構造解析のため のタンパク質結晶化促進にも利用可能であろう。た だし，目的の構造を特異的に認識するモノクローナ ル抗体を作製することは，かなり難度の高い作業で あることが予想され，ADLib システムのハイス ループット化による実施が必要である。

5-4. ハプテンに対するモノクローナル抗体の作 製例低分子・ハプテンのような動物個体での免 疫が困難な物質についても，原理的には ADLib シ ステムを適用することができる，具体的な例とし て, 分子量 389 の Fluorescein isothiocyanate (FITC) ハプテンに対する抗体作製例を Fig. 6 に示す。こ の場合，キャリアータンパク質としてウシ血清アル ブミン（BSA）を用い，BSAにFITCを共有結合 させ磁気ビーズに結合させた，得られたモノクロー ナル抗体は IgG-FITC には反応するものの IgG に は反応せず，FITCを認識しているものと考えられ る. その他, 磁気ビーズへの固定に工夫が必要なも のの，筆者らのグループではこれまでは抗体作製が 困難であることが知られていた糖鎖（癌関連糖鎖抗 原 LewisX などを含む複数）や糖脂質に対するモノ クローナル抗体の作製にも成功している.

5-5. ペプチドに対する抗体作製例 モノク ローナル抗体作製のニーズとしては，配列は既知で あるが精製タンパク質が存在しない因子に対する抗
Antigen used for slection: FITC-BSA

Antigen for ELISA assay: FITC-rabbit IgG

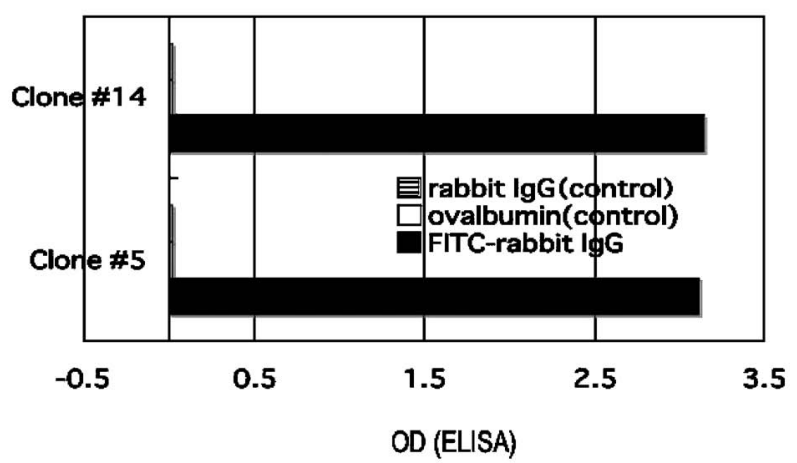

FITC<smiles>O=C(O)c1cc([N+](=O)[O-])ccc1-c1c2ccc(=O)cc-2oc2cc(O)ccc12</smiles>

$\mathrm{C}_{21} \mathrm{H}_{11} \mathrm{NO}_{5} \mathrm{~S}=389.38$

Fig. 6. Design of Anti-FITC Monoclonal Antibody by ADLib System

FITC is conjugated with bovine serum albumin (BSA), and then FITC/BSA-conjugated magnetic beads are subjected to ADLib system. The obtained antibodies specifically reacted with FITC-conjugated rabbit IgG, but not with rabbit IgG alone at all. Thus, the antibodies is expected to have specificity to the FITC hapten. 
体や，互いに非常によく似た配列を持つファミリー を形成する因子を識別する抗体，点突然変異などを 識別する抗体, リン酸化やアセチル化などの翻訳後 修飾を識別する抗体などの案件が存在する．これら のニーズに対応するためには，合成ペプチドに対す るモノクローナル抗体作製が有効である。ADLib システムを用いて，合成ペプチドに対するモノク ローナル抗体の作製を試みたところ，15 アミノ酸 程度の配列があれば，直接磁気ビーズに共有結合さ せることで，ADLib システムの適用ができること が明らかになった。したがって，リン酸化などの翻 訳後修飾を施した合成ペプチドを磁気ビーズに固定 すれば，これらの翻訳後修飾を認識する抗体の作製 も可能であろう。一方，ペプチドに対する抗体作製 はペプチドの配列の選択が重要であることが知られ ている．実際これまでの解析から，間接蛍光抗体染 色などに利用する抗体の作製には，多数の候補ペプ チドについて有効性を検討する必要のあることが分 かりつつあり, 注意を要する.

\section{6. 結 語}

$\mathrm{ADLib}$ システムは，ニワトリ B 細胞由来の培養 細胞株である DT40 細胞の抗体遺伝子ジーンコン バージョンを促進することを原理とした，モノク ローナル抗体を迅速に作製する抗体作製系である。 このシステムは，完全な ex vivo システムであり， これまで抗体作製が困難であった自己抗原や保存抗 原，小分子化合物，膜タンパク質，糖鎖，脂質など の物質に対するモノクローナル抗体作製に利用でき る。本システムの導入により，これまでは研究や創 薬の対象外であった生体分子も取り扱うことが可能 になるであろう。

加えて, ADLib システムは DT40 細胞の特質で ある高頻度標的遺伝子組換えを利用することで，得 られた抗体を実用に適した形態や高親和性型にカス タマイズすることが可能である。従来のモノクロー ナル抗体作製法では，一度入手した抗体の性能を向 上するには，重鎖・軽鎖抗体遺伝子のクローニン グ，遺伝子組換えや人工進化的手法を新たに利用す る必要がある，筆者らのグループでは，将来的には ADLib システムをさらに発展させて，これらのカ スタマイズ工程を 1 つの細胞株で一体的に実施する ことを目指して研究を進めている.

ADLib システムの迅速性は，昨今世界的な懸念
の対象となっているトリインフルエンザや SARS といった新興・再興感染症の発生時に威力を発揮す る可能性がある。これらの感染症が世界的なパンデ ミックに移行する前に, 迅速に診断薬や緊急治療薬 が開発できるようになるかもしれない。また， $\mathrm{AD}$ Lib システムの自動化によるハイスループット化も 現在開発中であり，今後は新しい抗がん剂や抗体医 薬の開発，又は「個の医療」に適した診断薬や抗体 医薬の開発も加速できるであろう.

謝辞本研究は, 科学技術振興機構と埼玉県に よる地域結集型共同研究事業「埼玉バイオ・プロジ エクト」, 科学技術振興機構・シーズ育成試験によ る支援を受けて実施されたものです。また，本研究 の一部については，NEDO の産業技術実用化開発 補助事業・ベンチャー技術開発助成事業の支援によ り，技術の実用化を行っている侏力イオム・バイオ サイエンスとの共同研究で行われたものです，研究 の指導にあたられた独立行政法人理化学研究所・柴 田武彦上席研究員に感謝致します。また，共同研究 の実施に多大なご協力を頂いた京都大学医学部の武 田俊一教授，埼玉県中小企業振興公社の Lin Waka 博士，升岡美恵子氏，中村晃歩氏，陎カイオム・バ イオサイエンスの藤原正明代表取締役，橋本修一博 士，新井清子氏，土屋京子氏，浅川美奈子氏，針谷 直人氏に深く感謝致します。

\section{REFERENCES}

1) Köhler G., Milstein C., Nature, 256, 495-497 (1975).

2) Smith G. P., Science, 228, 1315-1317 (1985).

3) Seo H., Masuoka M., Murofushi H., Takeda S., Shibata T., Ohta K., Nat. Biotechnol., 23, 731-735 (2005).

4) Ohta K., Shibata T., Nicolas A., EMBO J., 13, 5754-5763 (1994).

5) Yamada T., Mizuno K., Hirota K., Kon N., Wahls W.P., Hartsuiker E., Murofushi H., Shibata T., Ohta K., EMBO J., 23, 1792-1803 (2004).

6) Buerstedde J. M., Reynaud C. A., Humphries E. H., Olson W., Ewert D. L., Weill J. C., EMBO J., 9, 921-927 (1990).

7) Buerstedde J. M., Takeda S., Cell, 67, 179188 (1991). 
8) McCormack W.T., Thompson C.B., Genes Dev., 4, 548-558 (1990).

9) Muramatsu M., Sankaranand V. S., Anant S., Sugai M., Kinoshita K., Davidson N. O., Honjo T., J Biol. Chem., 274, 18470-18476 (1999).

10) Muramatsu M., Kinoshita K., Fagarasan S., Yamada S., Shinkai Y., Honjo T., Cell, 102, 553-563 (2000).

11) Arakawa H., Hauschild J., Buerstedde J.M., Science, 295, 1301-1306 (2002).
12) Harris R. S., Sale J. E., Petersen-Mahrt S. K., Neuberger M. S., Curr. Biol., 12, 435-438 (2002).

13) Sale J. E., Calandrini D. M., Takata M., Takeda S., Neuberger M. S., Nature, 412, 921 -926 (2001).

14) Cumbers S. J., Williams G. T., Davies S. L., Grenfell R. L., Takeda S., Batista F. D., Sale J. E., Neuberger M. S., Nat. Biotechnol., 20 , 1129-1134 (2002). 